\title{
低温プラズマによる表面改質
}

一粉体, 繊維への応用一

\author{
入山裕 \\ 山梨大学教育人間科学部 -400-8510 山梨県甲府市武田 4-4-37 \\ (1998 年 5 月 1 日受理)
}

\section{Surface Modification by Low-Temperature Plasma}

-Application to Powders and Fibers -

Yu IRIYAMA

Faculty of Education and Human Science, Yamanashi University 4-4-37 Takeda, Kofu, Yamanashi 400-8510

(Received May 1, 1998)

Surface modification by low-temperature plasma was reviewed. Plasma treatments of powders and fibers (fabrics) were focused, and the literatures published last five years concerning the treatments were introduced and discussed. In the plasma treatment of powders, some good devices for the reactor systems are required for uniform and efficient treatments. Recently, plasma-induced graft polymerization has been applied to powdery materials, which are expected to be used as new dispersing particles in hybrid systems. In the plasma treatment of fibers, many kinds of fibers have been proceeded for different purposes. Recently, high-strength fibers, such as aramid and carbon fibers, are often treated by plasma for the use of fiber-reinforced plastic (FRP). The strength of the FRPs with those plasma-treated fibers has been improved.

\section{1. は じめに}

プラズマとは電離した気体のことで，通常の気体より 高いエネルギー状態にあることから，固体，液体，気体 に次ぐ第四の状態と呼ばれることもある。プラズマはそ の電子温度とガス温度との関係から平衡プラズマ, 非平 衡プラズマに大別される。すなわち, 電子温度, ガス温 度ともに高温で平衡状態にあるのが平衡プラズマで高温 プラズマとも呼ばれ, 電子温度だけが高くガス温度がそ れほど高くないプラズマが非平衡プラズマで低温プラズ マとも呼ばれる。化学の分野では通常後者の低温プラズ マが用いられる。化学反応に利用されるプラズマは放電 で得られ, その周波数は直流からマイクロ波までさまざ まであるが，放電形態としては主に電圧が〜数百 $\mathrm{V}$ ，電 流が〜数百 $\mathrm{mA}$ のグロー放電が用いられる。

プラズマで引き起こされる化学反応には, 気相中での 合成反応や粉体の生成などプラズマ空間で完結する反応 もあるが，通常は電極や反応器壁も含めた固体基板表面 で起こり, 乾式でそれら基板のバルクの性質を変えるこ

E-mail: iriyama@kkb.yamanashi.ac.jp
となく表面のみの性質を変える「表面改質」がプラズマ 技術の最大の魅力の 1 つであろう。

プラズマによる表面改質は, 大きくプラズマ重合とプ ラズマ処理に分けられる。この分類は, 基本的に用いる ガスの種類によって決まってくる。すなわち, 重合性ガ スを用いるとプラズマ重合, 非重合性ガスを用いるとプ ラズマ処理になる。

プラズマ表面改質の応用は分野を問わず，あらゆる固 体表面とあらゆるガスとの無限ともいえる組み合せで可 能である。実際, 年間 200 報以上出版されているプラズ マ表面改質に関する研究論文の中身は多岐にわたってい る。本稿ではもちろんそのすべてを網羅することはでき ないので, 最近話題を集めている粉体と繊維（布）に焦 点を当て, 過去 5 年の比較的新しい論文の中から興味あ る研究を紹介する。なお，表面処理以外のプラズマ技術 全般に関しては，成書を参照していただきたい ${ }^{12}$ 2)。

\section{2. 粉体への応用}

粉体は他の材料に見られないその特異な形態から, 粉 体として単独でも，あるいは複数の物質の組み合せから なる複合材料の構成要素として広く利用されている。特 
に複合材料に用いられる場合は, 複合する他の物質等と の親和性, 相溶性が重要で, そのために表面処理が必要 になる場合が多い。それら粉体の表面処理は通常, 湿式 で行われるが, プラズマでも可能であることが多数報告 されている。プラズマを用いるメリットは乾式であるこ とのほかに, やはりバルクの性質を変えることなく極表 層のみの性質を変えることができるということである。

しかしながら, 必ずしもプラズマが粉体の処理に適し ているという訳ではない。逆に気相減圧下で行うことが 粉体の取り扱いを難しくしている。特に粒径が小さくな ればなるほど表面積が増大し, 処理すべき面積が大きく なり, 均一処理および効率的処理が大きな問題として立 ちはだかる。これは粉体のプラズマ処理には常に存在す る問題であり, それらを解決するためにそれぞれの研究 者が独自の工夫を凝らしているところである。

Inagaki らは, カーボンブラックをトナーとするコピ 一機のキャリアに用いられる数十 $\mu \mathrm{m}$ のマグネタイトお よびポリエチレン粒子を, $\mathrm{Ar} / \mathrm{C}_{2} \mathrm{~F}_{4}$ の混合気体を反応器 の下部から上方に吹き上げながら粒子を流動化し, 同時

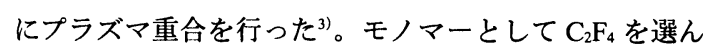
だのは, その付加重合体であるポリテトラフルオロエチ レン (PTFE) (-CF $\mathrm{CF}_{2}-\mathrm{CF}_{2}$ 蒲ポリマーの中で最も負に帯 電しやすい性質を持つためで, 実際, 粒子表面に F/C が 1.5 程度と PTFE ほどではないがフッ素含有率の比較 的高い重合膜が得られた。そのプラズマ重合処理したマ グネタイトをトナーとともに強制擋拌し, 摩摖電気量を 測定したところ未処理の $10 \mu \mathrm{C} / \mathrm{g}$ 程度に対して $20 \mu \mathrm{C} / \mathrm{g}$ 以上と 2 倍以上の効率で帯電することがわかった。

Nakahara らはガスクロマトグラフィーの固定相に使 われるカーボンブラック (CB) と活性炭を $\mathrm{CF}_{4}$ プラズ マで処理し, 分離能を調べだ)。ここで彼らが用いた装 置は, 平行平板の電極を持つ反态器で, 活性炭の場合は 機械的に振動を加えて均一に処理できたが, CB は凝集 しやすいため振動させずに行っている。処理した結果, ともにC-Fn に関する結合が大量に生成していることが $\mathrm{X}$ 線光電子分光法（XPS）スペクトルから明らかになっ たが, $\mathrm{CB}$ では-CF 結合が多く, 活性炭では- $\mathrm{CF}_{2}$ と- $\mathrm{CF}_{3}$ 結合が多く生成していた。(一見, 見過ごされがちでは あるが CB と活性炭の性質はかなり違うようである。） そのように処理した活性炭をガスクロマトグラフィーの 固定相として都市ガスを分離したクロマトグラムを Fig. 1 に示す。保持時間が全体的に短くなり, $\mathrm{CF}_{4}$ プラズマ の効果が現れていることがわかる。著者らは表面の-CF の影響と結論づけているが，比表面積など形態の変化も 検討の必要があるのではないだろうか。

Donnet らは黒鉛化カーボンブラック（比表面積 : 38

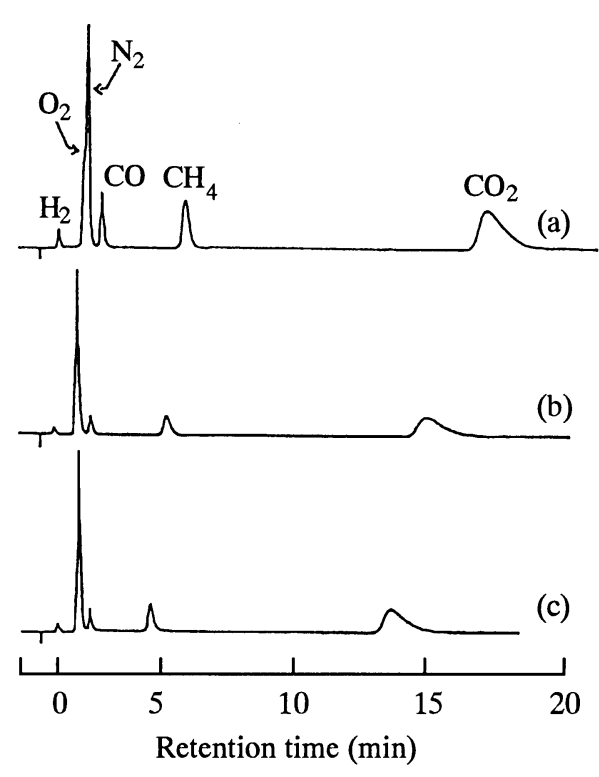

Fig. 1 Gas chromatograms of a town gas analyzed with a column filled with plasma-treated active carbon. ${ }^{4)}$ (a), non-treated; (b), $1 \mathrm{~W}, 5 \mathrm{~min}$; (c), $50 \mathrm{~W}, 60 \mathrm{~min}$.

$\left.\mathrm{m}^{2} / \mathrm{g}\right)$ を大気圧下で各種プラズマで処理し, その処理 効果を走查型トンネル顕微鏡（STM）とXPS で分析評 価した ${ }^{5)}$ 。その結果, 空気, $\mathrm{NH}_{3}, \mathrm{Ar}$ プラズマ処理では STMによる原子レベルの観察では黒鉛構造が破壊され ていることがわかった。水素プラズマでは黒鉛構造はほ とんど破壊されなかった。（化学反応性も 1 つのファク ターではあるが，水素はマスが小さいため一般にスパッ タリングの効果は小さいといわれている。）そしてこの 黒鉛構造の破壊の度合いが, 表面の化学組成より, 表面 エネルギーに強く影響を及ぼすことを示唆する結果が得 られている。

ポリマー微粒子のプラズマ処理も多く報告されてい る。

Kodama らは, ポリスチレン（PS）とポリメタクリル 酸メチル（PMMA）の微粒子を用い, $\mathrm{N}_{2}$ と $\mathrm{O}_{2}$ プラズマ で処理し, 静電気の発生の様子の違いを調べた6)。プラ ズマにはマイクロ波を用い, 微粒子はプラズマ領域の下 流でマグネチックスターラーで擋拌して処理した。処理 したポリマー微粒子は強磁性粒子と混合し, 静電気を測 定した。その結果, PMMA ではいずれのプラズマ処理 後も際だったチャージの変化は見られなかったが, $\mathrm{N}_{2}$ で処理した PS では表面組成でN が幾分増加し, チャー ジはプラス側にシフトした。彼らはNはドナーとして 働き,その結果プラス側にシフトしたと結論ゔけている。 伊藤らは, アクリルースチレン架橋粒子（粒径 $6.3 \mu \mathrm{m}$ ) 
を $\mathrm{O}_{2}$ のマイクロ波プラズマで処理し, 表面を活性化さ せたあと, 湿式でニッタルコーティングを行い, 均一に 金属がコーティングされたポリマー微粒子を得た”。二 ッケルコーティングの詳細は省くが, 未処理の粒子表面 にはほとんど被覆されないのに対し， $\mathrm{O}_{2}$ プラズマ処理 した粒子には金属がほぼ均一に被覆され，プラズマで表 面が適当に活性化されることがわかった。

Brown らは, マイカ（1 cm 角）を出力を変えながら Ar プラズマで処理し, 原子間力顕微鏡 (AFM) とXPS で分析した ${ }^{8)}$ 。AFM の結果からは，スパッタリングで表 面が削られていることが観察され，その表面の凹凸はパ ワーが高くなるほど大きく不均一になることがわかっ た。また, XPS から得られた表面の化学組成では, 酸 素のような軽い原子はスパッタリングで減少し, その結 果, アルミニウムやシリコンなど比較的重い元素が濃縮 されることがわかった。

粉体の中では顔料のプラズマ処理もこれまで数多く報 告されている。

まずは直接の顔料の処理ではないが，Homilius らは， ベンゼンのプラズマ重合過程に色素（ローダミン $6 \mathrm{G}$ ) を反応器内で界華させ, その色素で着色された重合膜を 作製した9)。得られた膜中の色素は, ほとんど化学構造 が破壊されておらず，可視吸収分光測定からはローダミ ン $6 \mathrm{G}$ 特有のスペクトルが得られた。また彼らは, 色素 と同時に銀を加熱蒸発させながら重合膜に取り込むこと にも成功し, 得られた膜中の色素の蛍光発光挙動が変化 していることを見い出した。

上記と同じグループの Werner らは反応器内で銀ある いは銅を加熱して昇華させながらへキサメチルジシラザ ンをプラズマ重合して, 銀あるいは銅を含有した重合膜 を作製している ${ }^{10)}$ 。そしてその膜に Nd : YAGレーザー を照射し, 金属をアニールして金属粒子のサイズや形状 を変化させる試みを行った。その結果, 透過型電子顕微 鏡（TEM）で観察したところアニーリング後は粒子の サイズ, 形が揃っており, 光学特性も変化することがわ かった。

顔料の表面処理は顔料がよく分散した㙦料を作る上で 重要な工程である。よい顔料分散を得るためには, ポリ マーと顔料との親和性の向上が最も重要な要素である が，もし顔料とポリマーが化学結合によって一体化して いるとすればもはや顔料の分散性の心配は必要ないので はないかと考えられる。このような考え方は顔料分散だ けに限らず, 各種複合材料の作製あるいは粉体の機能化 の観点から, 粉体からのグラフト化ということで種々の 方法で取り組まれている。そしてこのグラフト化にもプ ラズマが利用できる。すなわち, プラズマにより表面に

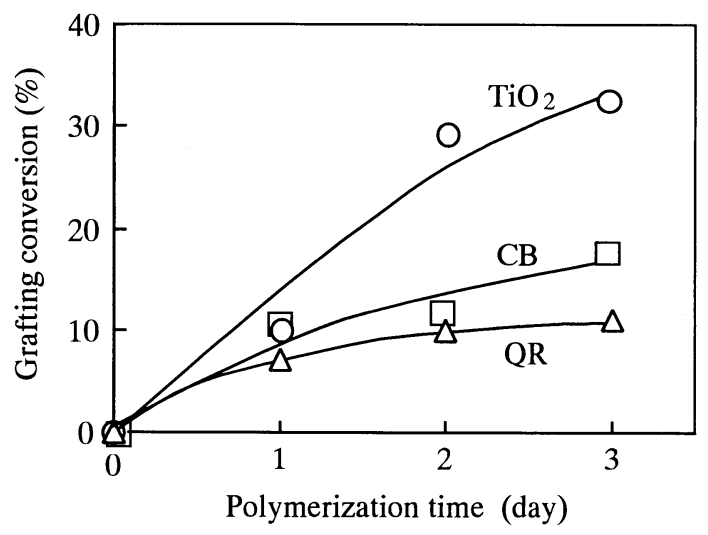

Fig. 2 Relationship between grafting conversion and polymerization time in plasma-induced graft polymerization of acrylic-monomer mixture onto pigments. ${ }^{14)}$ $\mathrm{TiO}_{2}$, titanium dioxide; CB, carbon black; $\mathrm{QR}$, quinacridone red.

ラジカルを生成し, ラジカル重合性のモノマーを接触さ せることにより行うもので, プラズマ開始グラフト重合 として繊維（布）やフィルムにはかなり以前から応用さ れている ${ }^{11 \sim 13)}$ 。粉体に対しても, 最近その可能性が示さ れている。プラズマ開始によるグラフト化のメリットは, もとの表面に官能基等の足場が存在しなくても, 基本的 にあらゆる表面からグラフトが可能で, また重合む加熱 の必要なく開始されることである。

筆者らはフラスコ回転式の粉体プラズマ処理装置に, 減圧下でモノマーを導入できるラインを取り付け, 室温 で粉体のグラフト化を行った ${ }^{14)}$ 。 Fig. 2 は $\mathrm{TiO}_{2}$, カーボ ンブラック (CB), キナクリドンレッド ( $\mathrm{QR})$ といっ た顔料を $\mathrm{O}_{2}$ プラズマで 1 時間処理した後, 水性塗料系 に用いられるアクリルモノマー混合物を導入した時の重 合時間とグラフト率を示している。重合速度は極めて遅 いが確実にグラフト重合が進行していることがわかる。 またこの中で特に $\mathrm{TiO}_{2}$ と $\mathrm{QR}$ は水性塗料化した時, 分 散性が向上することも明らかになった。

Tian らは重合直後のポリエチレン微粒子に Ar プラズ マを照射し, その後スチレンを加えることでグラフト化 を行った ${ }^{15)}$ 。通常のポリエチレンに比べ, プラズマ照射 により活性中心が生成しやすく, グラフト化む効率よく 行われることがわかった。

このプラズマ開始グラフト重合については, 井原らも ポリスチレンパウダー（粒径 $6 \mu \mathrm{m} ）$ に水のプラズマを 照射し, アクリルアミドやメタクリル酸 2-ヒドロキシ エチルといった水溶性モノマーがグラフトすることを確 認している ${ }^{16)}$ 。プラズマガスに水を使うと, 水溶性モノ マー（水溶液）との親和性がよくなり, 均一にグラフト 
されることを指摘している。また, 水溶性ポリマーでグ ラフトされたポリスチレンは水中での分散性が大きく向 上した。

\section{3. 緎維への応用}

まず最初に，プラズマの透過性を調べる目的で，重ね 合わせた布をフッ化炭素プラズマで処理した基礎的な研 究から紹介する。

Yasuda らはポリエステル（ポリエチレンテレフタラ 一トとポリブチレンテレフタラートの混合物）の不織布

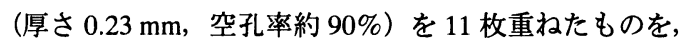
$\mathrm{C}_{2} \mathrm{~F}_{4}$ と $\mathrm{CF}_{4}$ プラズマで処理し, その効果がどこまで届 くかを調べた"17。一般にプラズマはある程度の容積の空 間がなければ発生せず，またプラズマ自体は X 線のよう な透過能力がないため, プラズマで直接処理されるのは 基本的にプラズマに接している表面だけである。しかし プラズマ中には多くの種類の活性種が存在し, またプラ ズマにより誘起された二次活性種の種類も多く, その中 には狭い空間に入り込めるものもあり, 結果としてプラ ズマの影響が内部まで届くことはある程度予想される。

ここで用いられた $\mathrm{C}_{2} \mathrm{~F}_{4}$ と $\mathrm{CF}_{4}$ はともに有機ポリマー 表面の疎水化には非常に効果的なプラズマガスである が, その反応機構は全く異なっている。すなわち, $\mathrm{C}_{2} \mathrm{~F}_{4}$ は二重結合があり重合性で, フッ素を多く含む疎水性の 薄膜, いわゆるプラズマ重合膜を表面に形成する。一方, $\mathrm{CF}_{4}$ は非重合性で, 重合膜は形成せず $\mathrm{CF}_{3}$ など疎水性の
フッ化炭素基が表面の水素などと置換して表面を踈水化 する。したがって布の処理を考えた場合, $\mathrm{C}_{2} \mathrm{~F}_{4}$ では重 合膜が形成されるために布の空孔がブロックされ易く, $\mathrm{C}_{2} \mathrm{~F}_{4}$ 由来の化学種の内部一の浸透は少ないと考えられ る。Fig. 3 に $\mathrm{C}_{2} \mathrm{~F}_{4}$ と $\mathrm{CF}_{4}$ プラズマで, 処理時間を変えて いった時の各層の布表面のフッ素と炭素の比を示す。上 で予想した通り， $\mathrm{C}_{2} \mathrm{~F}_{4}$ では下層のフッ素化があまり進 行しておらず第 1 層と第 11 層では大きな差が見られる のに対し, $\mathrm{CF}_{4}$ ではある程度の時間処理すれば下層でも 上層に匹敵するほどのフッ素化が進行しており, $\mathrm{CF}_{4}$ 由 来の化学種（フッ素）が内部深く入り込んでいることが わかる。

上記の結果から，非重合性ガスを用いると，布の内部 もある程度ブラズマで処理することが可能といえる。た だし, 織布で糸が重なっている部分は, マスクされた状 態と同じで, 改質されることはない。また，布に限らず, プラズマ空間とつながっていれば, 各種多孔性材料のプ ラズマが発生しない穴の奥まで処理は可能であると考え られる。

次に，同じ $\mathrm{CF}_{4}$ を用いた絹のプラズマ表面処理に関し ておもしろい報告がある。

西川らは綟の $\mathrm{CF}_{4}$ プラズマ処理において期待したほど 疎水化が進まないといら疑問から, 組（絧布から調整し たフィブロイン膜）表面の $\mathrm{CF}_{4}$ プラズマによる変化を $\mathrm{XPS}$ などで詳しく調べた ${ }^{18)}$ 。 $\mathrm{CF}_{4}$ は先に述べたように単 独では重合しないが，多くのポリマーを効率よく疎水化

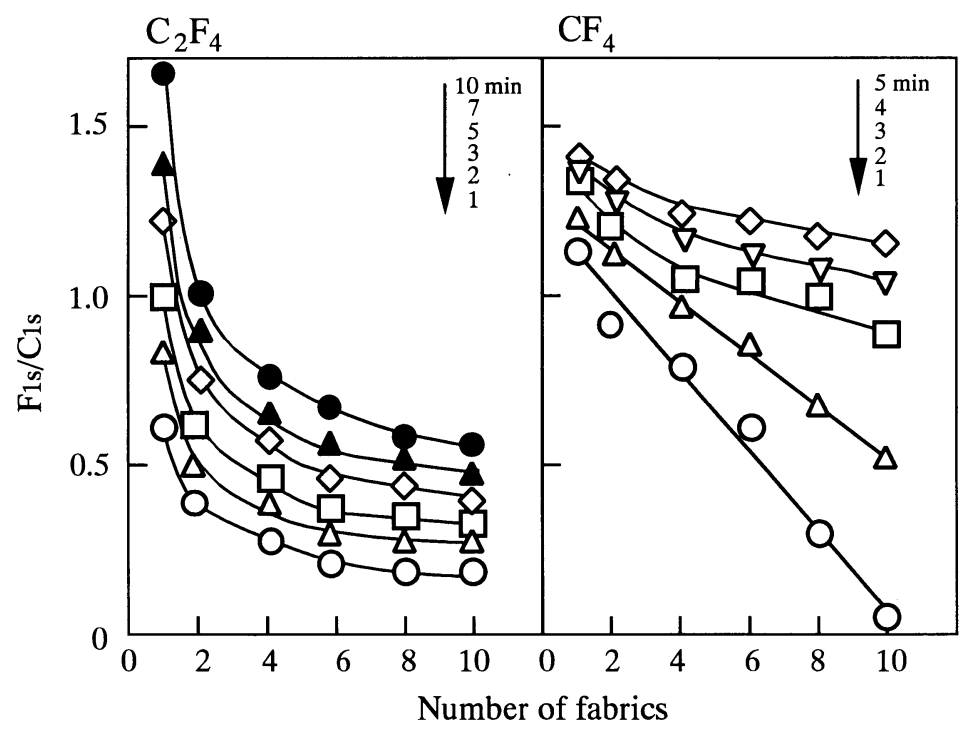

Fig. 3 Atomic ratio of $F_{1 s} / C_{1 s}$ on each surface of the 11-ply polyester fabrics sheet after plasma treatments with $\mathrm{C}_{2} \mathrm{~F}_{4}$ and $\mathrm{CF}_{4}{ }^{17)}$ Time in the figure denotes treatment time. 


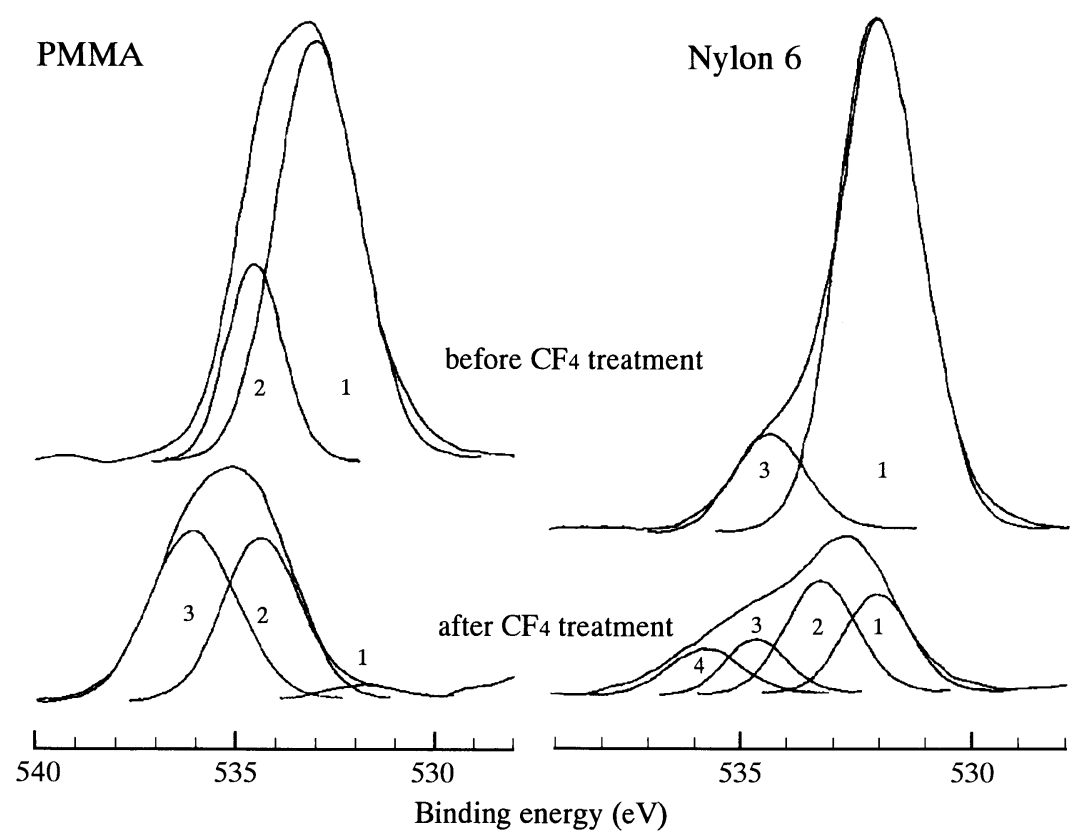

Fig. $4 \mathrm{O}_{1 \mathrm{~s}}$ XPS spectra of PMMA and nylon 6 powders before and after $\mathrm{CF}_{4}$ plasma treatment. ${ }^{19)}$

する。また一方で, $\mathrm{CF}_{4}$ は反応性が高く, 半導体工業な どではシリコンのプラズマエッチングガスとして疎水化 とは全く異なる反応に広く使われている。彼らは絧フィ ブロイン膜を $\mathrm{CF}_{4}$ プラズマで処理し XPS で調べたとこ ろ， $C_{1 s}$ スペクトルではフッ素と結合した炭素のピーク が高エネルギー側に幅広く見られ，表面が疎水化されて いるであろうことが十分予想された。しかし，ポリマー の疎水化では普段はあまり注目されないXPS の $\mathrm{O}_{1 \mathrm{~s}}$ ス ペクトルを見たところ, 通常の有機化合物にはないピー クが高エネルギー側に観察された。これはイオン化した 酸素と考えられ, 彼らは, 絧のペプチド結合が分解して 酸フッ化物が生成していると結論ゔけた。プラズマ中の フッ素の $\mathrm{F}^{-}$の存在およびその反応性の高さは以前から よく指摘されていることでもあり, 非重合性の $\mathrm{CF}_{4}$ プラ ズマでは起こりうる反応であろう。

同様な $\mathrm{CF}_{4}$ プラズマ処理によるポリマーの分解は，ナ イロンの主鎖や，アクリルポリマーの側鎖で起こり，酸 フッ化物が生成していることが XPS の $\mathrm{O}_{1 \mathrm{~s}}$ スペクトル で示唆されている。Fig.4は, 筆者らが行った実験で, 粉体ではあるが $\mathrm{CF}_{4}$ プラズマで処理した PMMA とナイ ロン 6 の XPS $\mathrm{O}_{\mathrm{is}}$ スペクトルであるが，プラズマ処理前 に比べ， $\mathrm{CF}_{4}$ 処理後は通常の有機ポリマーには見られな いピークが高エネルギー側に新たに生成している ${ }^{19)}$ 。以 上のことから, 重縮合系のポリマー, 例えばナイロンや ポリエステルを $\mathrm{CF}_{4}$ で処理するときには分解についても
注意が必要なようである。

次に, プラズマ処理では以前から研究報告の多い羊毛, ナイロン, ポリエステルに代わって, 最近頻繁に取り上 げられるようになった, 高強度のアラミド瀻維や炭素(カ 一ボン）瀻維のプラズマ処理について解説する。

アラミドはその分子構造が剛直で高強度であるが，一 般に接着性や染色性が悪く, プラズマを利用してそれら を改善する研究が行われている。プラズマによる一般的 な改質の方向としては他の材料同様, 表面の親水性化と 粗面化である。

Kobayashi らは後者の方法で, 前もって染色したアラ ミドを，その染色性の悪さを補うために，Ar雾囲気下 で通常のプラズマとスパッターエッチングにより表面に 微細な凹凸を作り濃色化を試みた ${ }^{20)}$ 。3 種類のアラミド (テクノラ, ケブラー, コネックス)を処理したところ, 処理時間の増加に伴って明るさの指標である $L^{*}$ 值が減 少すると同時に Table 1 に示すように色差 $\left(\Delta E^{*}\right)$ が増 大し, 濃色化が進行した。この濃色化の程度と表面に生 成した微細な凹凸の程度は走查型電子顕微鏡（SEM） での観察によると明らかに相関が見られる。ただ Table 1からわかるように, アラミドの種類によって結果が大 きく異なるのはおもしろい。また，通常のプラズマとス パッターエッチングを比較するとスパッターエッチング の方が効果的であることがわかる。このような微細な凹 凸の形成および濃色化はポリエステル瀻維では以前から 
Table 1 Color difference $\left(\Delta E^{*}\right)$ of black-dyed aramid fibers after Ar plasma treatment and sputter etching. ${ }^{20)}$

\begin{tabular}{cccccccc}
\hline \multirow{2}{*}{$\begin{array}{c}\text { Treatment } \\
\text { time(s) }\end{array}$} & \multicolumn{3}{c}{ Plasma treatment } & & \multicolumn{3}{c}{ Sputter etching } \\
\cline { 2 - 3 } \cline { 6 - 8 } & Technora & Kevlar & Conex & & Technora & Kevlar & Conex \\
\hline 0 & - & - & - & & - & - & - \\
30 & 0.5 & 0.5 & 0.4 & & 4.6 & 1.9 & 1.8 \\
60 & 0.8 & 0.6 & 0.4 & & 6.5 & 3.6 & 1.8 \\
180 & 3.4 & 0.6 & 0.4 & & 9.0 & 8.6 & 1.8 \\
300 & 4.2 & 1.2 & 1.3 & & 9.9 & 8.9 & 1.8 \\
\hline
\end{tabular}

単純な不活性ガスプラズマで行われていたが，アラミド の場合は積極的なスパッターエッチングが必要なようで ある。ただ，もともと染色性の悪いアラミドだけに，衝 撃などであらかじめ染色した染料がはげ落ちないか心配 でもある。

そのほかに，アラミドを含む繊維の比較的基本的なフ ラズマ処理に関する総説も最近いくつか出ている21, 22)。

アラミド繊維や炭素繊維など高強度瀻維は, 補強材料 として繊維強化プラスチック（FRP）などに広く利用さ れている。FRP とはプラスチックの強度を高めるために 繊維を充填した複合材料で，プラスチックと繊維の組み 合せに特に制限はないが，一般に親和性のよいものの組 み合せが強度化の効果が高い。そこで親和性を高めるた めに補強瀻維の表面処理が重要になる。通常行われる湿 式法に限らず, プラズマも表面処理の有効な手段である。

Jin らはアラミド繊維を空気プラズマで処理した後ア クリル酸（AA）とアクリル酸エチル（EA）でグラフト 重合し，エポキシとのFRPを作製した ${ }^{23)}$ 。緎維とエポ キシ界面の接着性の評価は単繊維引き抜き法 (single filament pull-out test）で行った。この方法では，一度の測定 で界面における最大ずり応力, 界面破壊エネルギー, 緎 維とマトリクスの摩擦力が得られ，FRPの界面の解析 には非常に有効である。彼らは AA, EA 単独, AA : EA= $1: 1$ のグラフト重合を行いそれらと未処理などのアラ ミド繊維を用いた FRP を比較した。最大ずり応力と界 面破壊エネルギーを Table 2 に示したが，両者共に大き い值を示したのは $\mathrm{AA}$ と $\mathrm{AA}: \mathrm{EA}=1: 1$ でグラフトした むので，エポキシとの相互作用を高めるにはカルボキシ ル基が有効であると述べている。

Shaker らも同様にアラミド織維をプラズマ処理しエポ キシとの FRP を作製し，単緎維引き抜き法で評価して いる ${ }^{24)}$ 。プラズマ処理の方法は上記とは全く異なり，Ar でのエッチングとそれに引き続いてアリルアミンでプラ ズマ重合を行っている。未処理のアラミドを用いた FRP では，繊維の引き抜き荷重が $0.25 \sim 0.28 \mathrm{~N}$ であったが, アリルアミンを重合していくと，重合時間（重合膜厚） の増加に伴って引き抜き荷重も増加し 45 分の重合処理
Table 2 Results of single filament pull-out test for aramidepoxy FRP. ${ }^{23)}$

\begin{tabular}{lcc}
\hline Treatment & $\begin{array}{c}\text { Shear stress } \\
(\mathrm{MPa})\end{array}$ & $\begin{array}{c}\text { Energy of interface } \\
\text { fracture }\left(\mathrm{J} / \mathrm{m}^{2}\right)\end{array}$ \\
\hline Non & 21 & 45 \\
cleaned & 24 & 28 \\
$\mathrm{H}_{2}$ O-plasma-treated & 39 & 36 \\
AA-grafted & 47 & 48 \\
EA-grafted & 37 & 43 \\
AA-EA-grafted & 45 & 55 \\
\hline
\end{tabular}

で $0.5 \mathrm{~N}$ を越えるまで増加した。ただ，SEM 写真を見る 限りでは 45 分の重合での膜厚は $2 \mu \mathrm{m}$ をはるかに越え, クラックも生じており，そのようなアラミドが最も良い 性能を示すことに疑問は残るが，全般にアリルアミンの アミノ基がエポキシとの相互作用を強めていることは確 かであろう。

ポリエチレン繊維とカーボン織維をプラズマ処理した ものを用いた FRP に関する総説25) 興味深い。

筆者らは，ガラス繊維（織布）-エポキシの FRP で, ガラス繊維を各種プラズマで処理して FRP の強度を高

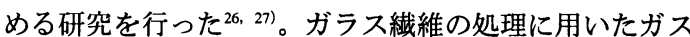
は, $\mathrm{Ar}$, 空気, $\mathrm{O}_{2}, \mathrm{NH}_{3}$ で，それらプラズマで処理し たガラス繊維を用いたエポキシとの FRP を作製し，強 度を引っ張り試験で調べたところ，プラズマ条件により 程度の差はあるものの，すべて未処理のものより高い引 っ張り強度を示した。

プラズマエネルギー密度と FRP の強度の関係は単純 ではなく, 強度が最高值を示す適当なエネルギー密度が それぞれのガスで存在した。これは，まず第 1 に表面が 改質されることによりエポキシとの親和性が高まり強度 の向上につながると予想されるのである程度のエネルギ 一密度は必要であるが，エネルギー密度が高すぎてもプ ラズマ照射の影響（加熱や活性種の物理的衝撃など）で 織維自体がダメージを受け強度の低下を招く恐れも予想 される。

ガス種については上記 4 種類の中では特に大きな違い は見られなかったが， $\mathrm{NH}_{3}$ プラズマで処理したガラス緎 維を用いた FRP が最も高い強度を示した。これは，ガ ラスの表面あるいはガラス織布作製時に添加するスター チを足場にアミノ基が生成し，エポキシとの相互作用を 強めているものと考えられる。

このスターチの存在む FRP の強度に影響を与えるこ とは当然で，そこで次にスターチを取り除く熱処理と $\mathrm{NH}_{3}$ プラズマの複合的な FRP の強度への影響を調べた。 処理が異なる 4 種類の瀻維でできた FRP の引っ張り強 度の結果を Table 3 に示す。プラズマ処理なしのもので 比較すると熱処理することにより強度は大きく低下す 
Table 3 Tensile strength of FRP with differently treated glass fabrics. ${ }^{26)}(\mathrm{MPa})$

\begin{tabular}{lcc}
\hline & Non-heat-cleaned & Heat-cleaned \\
\hline Non-plasma-treated & 205 & 133 \\
$\mathrm{NH}_{3}$-plasma-treated & 237 & 149 \\
\hline
\end{tabular}

る。これはスターチの有無よりは, 加熱によるガラスそ のものの強度の低下のためであると考えられる。 $\mathrm{NH}_{3}$ プ ラズマ処理したものを比較すると，熱処理したものもし ないものもプラズマ未処理に比べ強度は上昇するが，熱 処理してないほうが強度の上昇幅も大きく, $237 \mathrm{MPa}$ で上昇した。この結果からはスターチの存在が悪影響を 及ぼしていることは確認されず，逆にアミノ基などの官 能基の生成に有効に関与していることも考えられる。

大手らはFRP (プラスチック) ではないが，セメン 卜の補強材としてポリアクリロニトリルベースの炭素緎 維シートをプラズマ処理して用いた ${ }^{28)}$ 。プラズマ処理に は $\mathrm{O}_{2}$ と $\mathrm{CF}_{4}$ を使用し，炭素繊維シートを 11 枚積層して セメントとの複合材料を作製し， 3 点曲げ試験で強度を 調べた。その結果, 11 枚すべて $\mathrm{CF}_{4}$ 処理したシートを 用いたセメントの破壊荷重は未処理のシートを用いたも のより大きく上昇したが， $\mathrm{O}_{2}$ 処理シートのみ 11 枚では 逆にわずかに低下した。これは上でも述べたように，プ ラズマ照射により炭素繊維シートそのものの低下が考え られる。また，なかなか解釈は難しいが， $\mathrm{CF}_{4}$ と $\mathrm{O}_{2}$ 処 理したものを組み合せることにより $\mathrm{CF}_{4}$ 処理のみのもの より大きい破壊荷重が得られている。 $\mathrm{O}_{2}$ プラズマ処理 による炭素䋐維シートの強度の低下については, 彼らは シース電圧の影響と考え, 彼らが独自に開発した分岐回 路を用い，プラズマ処理に拉いてシース電圧をコントロ ールして材料への損傷を低減している29)。

\section{4.おわりに}

本稿で取り上げた粉体および繊維の中でも特に短緎維 はプラズマで処理しにくいものの代表で, それらの処理 には専用の装置を工夫しながら作製する必要がある。ま た，プラズマ表面処理においては装置条件も含めてパラ メータが多く, 反応機構も完全には解明されていないた め, 試行錯誤が求められる場合も多い。しかしながら, フィルム, シート, 長繊維など形状が単純であれば容易 に処理することができる。さらに，プラズマ表面改質は 固体およびガスの種類を問わず，あらゆる組み合せで可 能である。したがって何らかの固体材料を扱っていて, 表面性状に関する何らかの問題があり，プラズマ以外の 一般的な方法で解決できなければ，プラズマをトライし てみる価値は十分あるのではないだろうか。

\section{文献}

1) 日本学術振興会第 153 委員会編 : “プラズマ材料科 学ハンドブック” (オーム社, 1992).

2) 長田義仁編著 : “低温プラズマ材料化学”（産業図 書, 1994).

3) N. Inagaki, S. Tasaka and K. Ishii: J. Appl. Polym. Sci. 48, 1433 (1993).

4) M. Nakahara, K. Ozawa and Y. Sanada: J. Mater. Sci. 29, 1646 (1994).

5) J.-B. Donnet, W.-D. Wang and A. Vidal: Carbon 32, 199 (1994).

6) J. Kodama, R. Foerch, N.S. McIntyre and G.S.P. Castle: J. Appl. Phys. 74, 4026 (1993).

7) 伊藤征司郎, 南橋啓司, 塩川二朗 : 色材協会誌 67, 7 (1994).

8) N.M.D. Brown and Z.H. Liu: Appl. Surf. Sci. 90, 155 (1995).

9) F. Homilius, A. Heilmann and C. Borczyskowski: Surf. Coat. Technol. 74/75, 594 (1995).

10) J. Werner, A. Heilmann and O. Stenzel: Int. J. Electr. 77, 945 (1994).

11）畑田研司，小林弘明，増田 豊，北野幸重 : 高分子 論文集 38, 615 (1981).

12）長田義仁，入山 裕，大田 克：日化 1983,831 .

13) T. Hirotsu: J. Appl. Polym. Sci. 34, 1159 (1987).

14) Y. Iriyama and S. Ikeda: Polym. J. 26, 10 (1994).

15) J. Tian, X. Lin, B. Huang and J. Xu: Eur. Polym. J. 31, 755 (1995).

16）井原辰彦, 朝崎暢彦, 木卜光夫 : 色材協会誌 69, 307 (1996).

17) T. Yasuda, T. Okuno, M. Miyama and H. Yasuda: J. Polym. Sci.: Part A: Polym. Chem. 32, 1829 (1994).

18) 西川昭文, 真柄宏之, 嶋崎暢子: 繊維学会誌 50,274 (1994).

19) Y. Iriyama, K. Amemiya and T. Ihara: J. Photopolym. Sci. Technol. 8, 403 (1995)

20) S. Kobayashi, T. Wakida, S. Niu, S. Hazama, T. Ito and Y. Sasaki: J. Soc. Dyers Colour. 111, 72 (1995).

21) 脇田登美司, 解野誠司 : 表面技術 46, 1003 (1995).

22) 高田忠彦, 渡辺博佐 : トライボロジスト 41, 935 (1996).

23) S. Jin, C. Chang, X. Wang and Y. Yu: J. Adhes. 59, 251 (1996).

24) M. Shaker, I. Kamel, F. Ko and J.W. Song: J. Compos. Technol. Res. 18, 249 (1996).

25) R. Li, L. Ye and Y.-W. Mai: Composites 28 A, 73 (1997).

26) T. Ihara, T. Matsuoka and Y. Iriyama: J. Adhes. Sci. Technol. 10, 823 (1996).

27) Y. Iriyama, M. Taira, T. Ihara and T. Matsuoka: J. Photopolym. Sci. Technol. 10, 139 (1997).

28) 大手丈夫, 清水敬祐, 小島 昭, 古川 茂, 大谷杉 郎：炭素 1993 (158), 141.

29) 泉 順, 石原秀俊, 大手丈夫, 小島 昭 : 炭素 1997 (177), 64. 